\title{
コンクリートに埋設された鋼材の マクロセルおよびミクロセル腐食に関する研究
}

\author{
川東龍夫 ${ }^{1}$ ・ 小林孝 $^{2} \cdot$ 宮川豊章 $^{3}$ \\ ${ }^{1}$ 正会員 博(工) 近畿大学講師 理工学総合研究所（T577-8502 東大阪市小若江 3-4-1) \\ ${ }^{2}$ 正会員 博(工) 中部大学講師 工学部士木工学科（广487-8501 春日井市松本町 1200） \\ ${ }^{3}$ 工叫会員 工博 京都大学教授 大学院工学研究科 (T606-8501 京都市左京区吉田本町)
}

コンクリート中の銅材腐食を非破壊手法によって的確に把握することは, コンクリート構造物を維持管理 する上で重要な項目の一つである. しかし, 現在用いられている非破壊手法は，手法の種類と条件，測定値 の評価方法などの点で方法論的な検討が行われている段階にあり, 手法と評価方法の確立が望まれている.

本研究は，鋼材の腐食をマクロセル腐食，ミクロセル腐食に分けて評価することを目的に，大きさの異な る鋼板を用いたモデル試験供試体の電気化学的な経時変化を非破壊的に測定し，腐食に関する解析を行った。

これらの解析結果と腐食减量測定結果から，鋼材腐食をマクロセル腐食とミクロセル腐食によって区別す ることができ，それらを用いた鋼材の腐食量推定が可能であることを示した.

Key Words : chloride, steel corrosion, electrochemical method, half-cell potential, polarization resistance, concrete resistance, electric current, macro-cell, micro-cell, numerical analysis

\section{1.はじめに}

コンクリート中の鉄筋腐食を非破壊的に評価する手 法として, 自然電位法および分極抵抗法があげられる. このうち, 自然電位法は, 測定の簡便性と測定值の評 価の再現性から鉄笳腐食判定方法として現在最も広く 用いられている手法の一つである. また，分極抵抗法 は，鉄筋腐食速度の推定，あるいは腐食部位の劣化状 態の将来予測ができると考えられている. しかし，分 極抵抗法は，測定手法の種類と条件，あるいは測定值 の評価方法などの方法論的な検討が行われている段階 にあり，測定手法と評価方法の確立が望まれている ${ }^{11}$.

一方，コンクリート中の鋼材腐食はマクロセル腐食 とミクロセル腐食によって生じ，腐食はこれら両者が 混在して進行するものと考えられる. しかし，現況の 非破壊手法では両者を区別して推定することが難しい。 したがって，鋼材腐食のメカニズムを充分に把握した 上で，非破壊手法による鋼材腐食の評価方法を確立す ることは重要である.
最近，この種の研究は種々の手法が用いられ検討さ れてきている. たとえば, 各種の数值解析により腐食

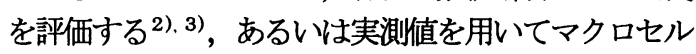
腐食およびミクロセル腐食を評価する ${ }^{4)}$ などの手法が 用いられている. しかし，実際の現象と整合性を保た せながら腐食をごく限られた部分に限定し，分極抵抗 法などの電気化学的な非破壊測定および解析によって, マクロセル腐食とミクロセル腐食の区別を行った上で 腐食量の推定を試みた報告は少ない。

本研究は，塩分による鋼板腐食をマクロセル腐食， ミクロセル腐食に区別して把握することを目的に，電 気化学的な非破壊手法を用いた測定と解析によって, 主として以下の 2 項目について検討を行った.

（1）自然電位とコンクリート抵抗の測定結果を用い たマクロセル腐食解析結果と, それらに分極抵抗も加 えた場合におけるマクロセル腐食解析結果の比較

（2）解析から得られるマクロセル腐食, 鋼板間電流 測定から得られるマクロセル腐食, および分極抵抗か ら得られる腐食の相互関係と腐食量の推定 


\section{2. 試験概要}

\section{（1）使用材料とコンクリート配合}

使用材料を衰-1 に示し，コンクリートの示方配合， 空気量, スランプ, 28 日強度の実測值を衰-2 に示す.

\section{（2）供試体}

コンクリートおよひ鋼板の形状を図ー1（a)に示す. 供試体は，以下の 2 種類をそれぞれ 2 体作成した. シリーズ 1 : マクロセル腐食を検討する目的で長 い鋼材を用いたもの(以下，Lと略称)

シリーズ 2 : マクロセルおよびミクロセルを検討 する目的で，短い鋼材の各リード線 を接続あるいは一時的な切り離しを したもの（以下， $\mathrm{S}$ と略称）

いずれの鋼板も材質，厚さ，幅は同一とし，腐食を 目的とした所定の露出面以外のエポキシ樹脂塗装，供 試体中の塩水添加セルを以下のように施した.

シリーズ 1 (L) の鋼板は, 厚さ $1.6 \mathrm{~mm}$, 幅 $15 \mathrm{~mm}$, 長さ $1930 \mathrm{~mm}$ の形状のものを用い，片面の $15 \times$ $1810 \mathrm{~mm}$ を除いた側面，および裏面全てを樹脂塗装 した. コンクリート打設時に，鋼板露出面の端部 1 カ 所に内径約 $10 \mathrm{~mm}$ の円筒を鋼板直上約 $5 \mathrm{~mm}$ まで挿 入し，円筒はコンクリート凝結後に取り除いた.この 形成された空洞を塩水添加用セルとした. 次に, シリ ーズ2（S）に用いた鋼板は厚さ $1.6 \mathrm{~mm}$ ，幅 $15 \mathrm{~mm}$, 長さ $98 \mathrm{~mm}$ で, 各供試体の両端にリード線取付用突 起が設けられたものを用いた．両端に使用する鋼板は 塩水添加用セル側を $168 \mathrm{~mm}$ ，もう一端を $158 \mathrm{~mm}$ と した. 各鋼板の露出面以外の裏面，側面，リード線取 付後の突起部分は L と同様に樹脂塗装し, 露出面長さ の合計を $1720 \mathrm{~mm}$ とした. 塩水添加用セルを形成す るための円筒設置と除去も L と同様である.

鋼板は型枠の内側に敷設された絶縁粘着シール上に 貼りつけ，その上からコンクリートを打設する方法と した。なお，脱型時およひ盖生期間中に供試体にひび 割れ発生の可能性が考えられたが，脱型時およひ試験 期間中におけるひひ割此は全く生じなかった.

\section{（3）稂生およひ謤境条件}

供試体は打設 48 時間後加 14 日間水中養生し, その後室内乾燥盖生を行った. 室内乾燥を所定期間行 った後，塩水添加用セル下にある鋼板を腐食させた。 特に，腐食位置を限定することと，実際の現象と同じ ようにコンクリート供試体内人塩分を浸透・拡散させ
るため，設けられた塩水添加用セルへ塩水を定常的に 供給した. 塩水は, $\mathrm{NaCl}$ 換算で $3 \%$ 質量濃度とし, 塩水ボトルから内径 $1 \mathrm{~mm}$ のシリコンチューブを介し て塩水添加用セルが常時満たされるように一日あたり 約 5〜6c割合で供給した。

\section{（4）測定項目}

測定は，電気化学的測定とコンクリートから鋼板を 取り出した後の腐食減量測定とした.

\section{a) 測定条件}

電気化学的測定は，湿布により供試体を充分に湿ら せた後に, 自然電位, 交流法による分極抵抗とコンク リート抵抗，および供試体 $\mathrm{S}$ における鋼板間電流の各 項目について行った（図-1 (a) 参照). 交流法の測定 条件は, 電圧を $\pm 10 \mathrm{mV}$ とし, 周波数は $10 \mathrm{~Hz}$ と $0.01 \mathrm{~Hz}$ の 2 種類とした. 自然電位，分極抵抗，コンクリート 抵抗の照合電極は全て飽和塩化銀電極を用い，交流法

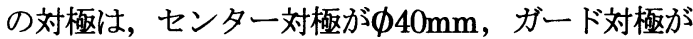
Ф106mm の二重刘極型りを用いた。

腐食減量は，鋼板試料を $10 \%$ 質量濃度のクエン酸 2 アンモニウム溶液に 24 時間浸漬し，その浸漬前後 の質量差㘦腐食减量を算出した。 なお，塗装の溶解 と付着細骨材が腐食减量へ影響を与えると考えられた ため，塗装された同じ種類の鋼板 3 枚を同一溶液に浸 漬寸ること，浸漬後の溶液を濾過して剥離した細骨材 の質量を求めることにより影響を除くこととした.

\section{b) 測定点数}

それぞれの供試体における電気化学的測定の測定位 置と測定点数を図-1 (b) に示寸.

供試体 Lの測定は, 自然電位を $50 \mathrm{~mm}$ 間隔の 37 箇所, 分極抵抗およびコンクリート抵抗測定を $100 \mathrm{~mm}$ 間隔の 18 籄所で行った. 供試体 $\mathrm{S}$ の測定は, 自然電 位を各鋼板の中央と，塩水添加セル付近および塩水添 加セルから最も離れた鋼板における端部を含めた 21 箇所とし，分極抵抗とコンクリート抵抗測定について も塩水添加セル内と両端部を除く同一䇢所の 18 箅所 とした. また，供試体 $\mathrm{S}$ の測定は，小鋼板のリード線 を接続した状態と一時的に接続を切り離した状態につ いてそれぞれ行った. なお，リード線の切り離し時の 測定には直前の接続時の状態が，接続時の測定には直 前の切り離し時の状態が，それぞれの測定に影響を与 えると考えられたため, 測定までの間電位測定を行い， 電位が安定するのを確認した後，各測定を行った。

供試体 $\mathrm{S}$ 電流は，鋼板間のリード線を接続したま まの状態で各鋼板間の電流を測定した. 
表-1 使用材料

\begin{tabular}{|c|c|c|}
\hline \multirow{3}{*}{ セメント } & & 高炉セメントB種，スラグ量 : $40 \%$, 密度 : $3.05 \mathrm{~g} / \mathrm{cm}^{3}$, ブレーン比表面積 : 398 \\
\hline & 化学成分 (\%) & $\begin{array}{l}\mathrm{SiO}_{2}: 25.4, \mathrm{Al}_{2} \mathrm{O}_{3}: 8.3, \mathrm{Fe}_{2} \mathrm{O}_{3}: 2.3, \mathrm{Ca} 0: 55.9, \mathrm{Mg} 0: 3.6, \mathrm{SO}_{3}: 1.9, \\
\mathrm{Na}_{2} \mathrm{O}: 0.25, \mathrm{~K}_{2} \mathrm{O}: 0.43, \mathrm{TiO}_{2}: 0.55, \mathrm{P}_{2} \mathrm{O}_{5}: 0.09, \mathrm{Mn} 0: 0.16 \text {, ig. loss }: 0.7\end{array}$ \\
\hline & 鉱物組成 $(\%)$ & $C_{3} \mathrm{~S}: 31, C_{2} \mathrm{~S}: 13, C_{3} \mathrm{~A}: 5, C_{4} \mathrm{AF}: 5$ \\
\hline & 細骨材 & 川砂，密度 : $2.55 \mathrm{~g} / \mathrm{cm}^{3}$ ，粗粒率 : 2.74 , 吸水率 $: 2.19$ \\
\hline & 粗骨材 & 研石, 密度: $2.67 \mathrm{~g} / \mathrm{cm}^{3}$, 粗粒率 : 6.29 , 吸水率 : 0.95 , 最大寸法 : $15 \mathrm{~mm}$ \\
\hline 龬 & & 鋼板，種類：一般構造用圧延鋼材，SS41(SS400)，材質：酸洗材，板厚：1.6mm \\
\hline
\end{tabular}

表-2 コンクリートの示方配合と実測值

\begin{tabular}{|c|c|c|c|c|c|c|c|c|c|c|}
\hline \multirow{2}{*}{$\mathrm{W} / \mathrm{C}$} & \multirow{2}{*}{$\begin{array}{c}\text { 細骨材率 } \\
\text { s/a }(\%)\end{array}$} & \multicolumn{5}{|c|}{ 単位質量 $\left(\mathrm{kg} / \mathrm{m}^{3}\right)$} & \multirow{2}{*}{ 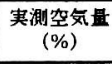 } & \multirow{2}{*}{$\begin{array}{c}\text { 本測スランン } \\
\text { (cm) }\end{array}$} & \multicolumn{2}{|c|}{28 日强度の奏测值 $\left(\mathrm{N} / \mathbf{m}^{2}\right)$} \\
\hline & & W & $\mathrm{C}$ & $\mathrm{s}$ & $G$ & AE剂 & & & 压縮 & 曲げ \\
\hline 0.5 & 46.8 & 185 & 370 & 755 & 899 & - & 2.0 & 8.5 & 33.9 & 5.6 \\
\hline
\end{tabular}
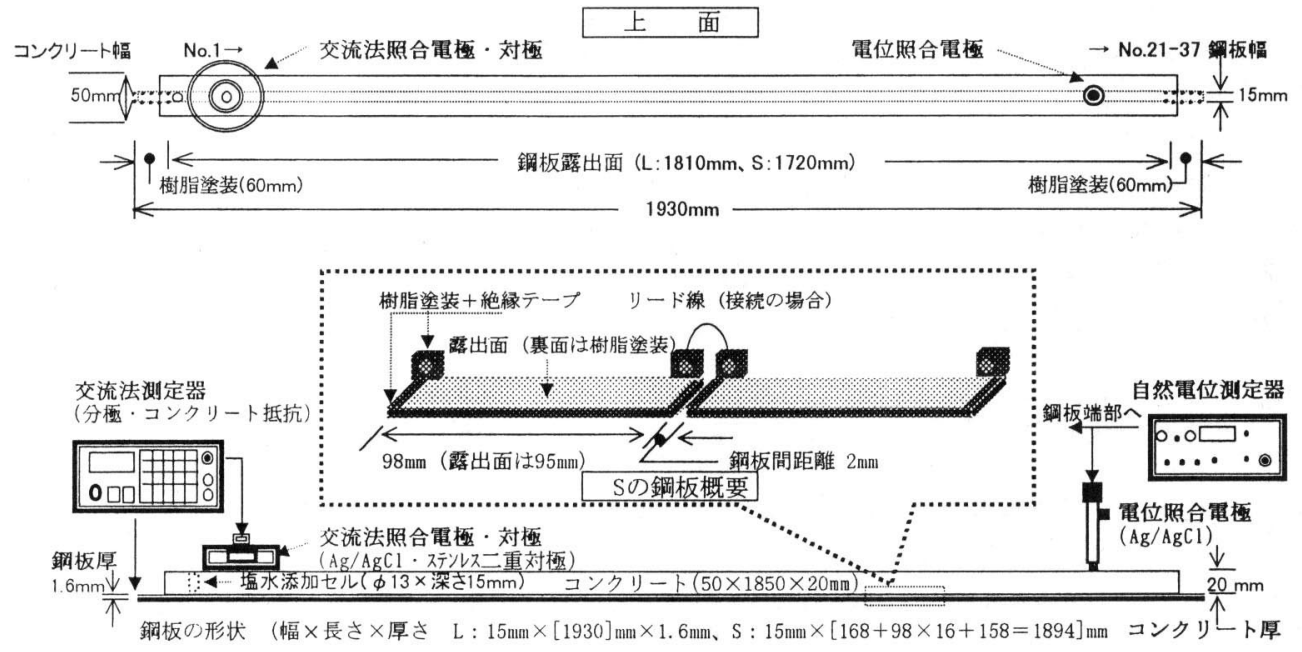

側 面

（a）鋼板・供試体形状，および測定概要

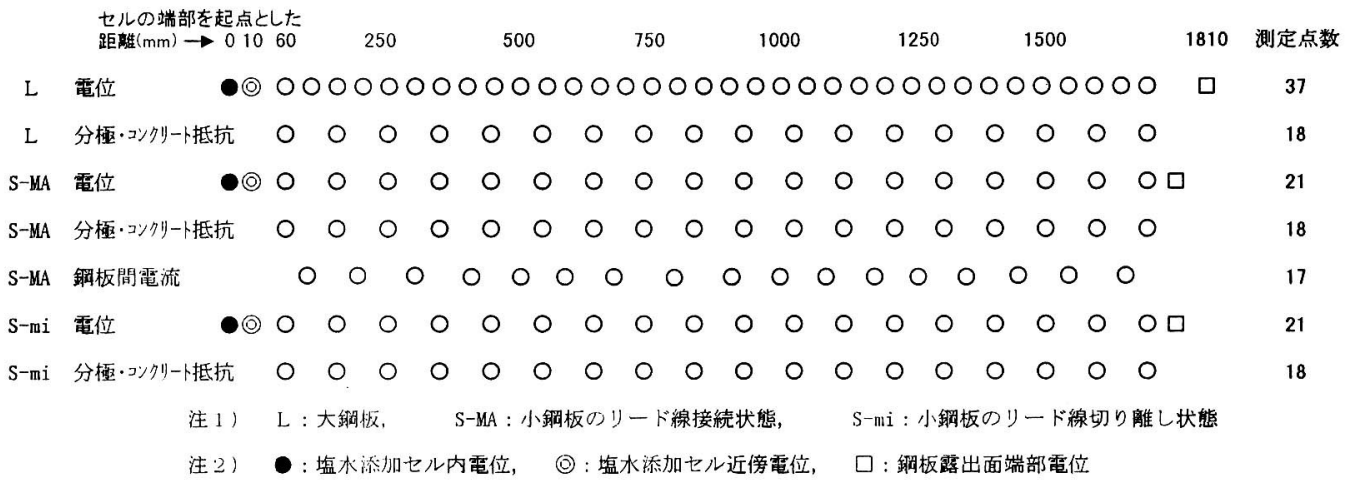

（b）各測定の測定位置

図-1 供試体の形状，主たる測定の概要と測定位置 


\section{3. 試金涻果と考察}

\section{（1）各測定值の経時変化}

\section{a) 平均電位の経時変化と電位分布}

塩水添加前後の供試体Lおよび供試体 Sにおける供 試体全体の平均電位経時変化を图一2に示す.

図一2 (a)では，水中養生および塩分添加前における 各供試体の平均電位が同じ様な変化を示している.

供試体Lおよび供試体 S の中から塩水を添加する供 試体をそれぞれ 1 体選び，塩水を塩水添加セル中に定 常的に添加した. これらの供試体をそれぞれ L1，S1 とする.

塩水を添加した後も室内乾燥養生を行っているが, 平均電位が著しく卑変する時期は，図-2 (b) に示され るように, L1 て塩水添加後約 800 時間, S1 で約 1300 時間となった. また，図一2 (b) 中の黒い知印に示さる ように，L1，S1 とも著しく卑変している期間は卑変 開始より約 300 時間と同程度で，乙の後緩やかな卑変 を示した. 卑変開始時期が異なったのは, 塩水添加セ ル直下のモルタル厚さの違いが影響し，鋼板への塩分
到達時期が異なったために生じたものと考えられる. このため, 腐食開始は, L1 て塩水添加後約 800 時間, S1 て塩水添加後約 1300 時間と考えられる. なお, 後 述するマクロセル腐食の数值解析には, 卑変が緩やか になる時期（L1 で約 1100 時間，S1 で 1600 時間） 以降の測定值を用いた。

塩水が添加された後の平均電位が卑変する前後にお ける供試体各点の電位分布を図一淙す.

L1 (335 時間)，およびリード線が接続された状態 のS1（336 時間）の電位は, 測定点間に大きな差が 認められない. しかし, 塩水添加セル付近の電位が卑 変した後は L1, S1 とも塩水添加セル付近が最も卑で, この点から離れるにしたがい塩水添加セル付近より貴 の值を示している. また, L1, S1 とも塩水添加セル から最も遠い部分でも自然電位はやや卑変しており， 塩水添加セル付近における不動態皮膜が塩分によって 破壊された影響を受けていると考えられる。一方，リ 一ド線が切り離された状態の S1 の電位は, 塩水添加 セル付近での変化は認められるものの, 他の部分では 各鋼板個別の変化を示している.

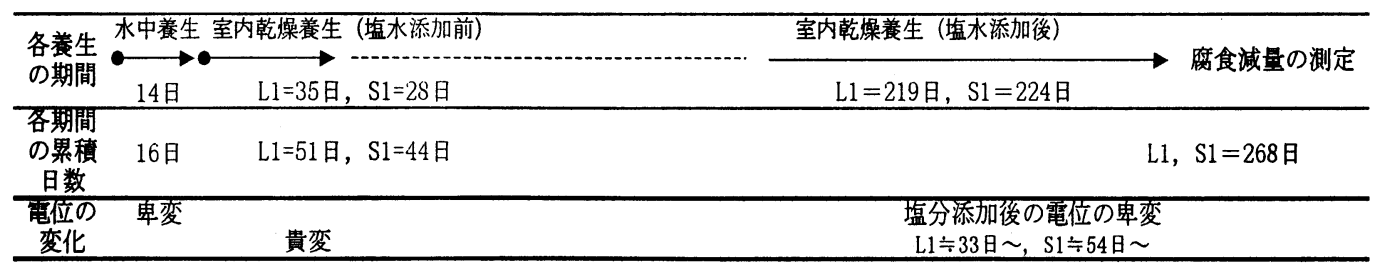

塩水添加供試体の選正

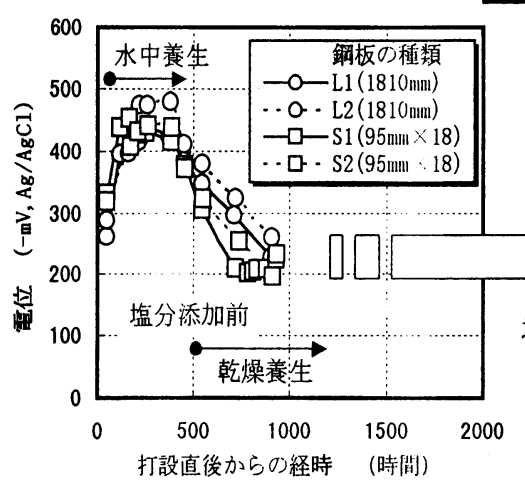

(a) 塩水添加前0)平均電位経時变化
室内乾燥養生後

L1(35日), S1(28日)

のセルに塩水添加

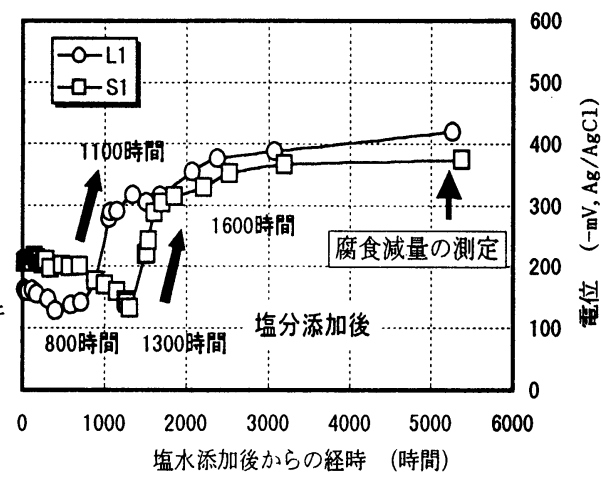

（b）塩水添加後の平均電位経時変化

図-2 各供試体における供試体全体の平均電位経時変化 


\section{b）分極抵抗とコンクリート抵抗の分布}

供試体 L1 および $\mathrm{S} 1$ における真の分極抵抗と見か けのコンクリート抵抗の分布をそれぞれ図-4の(a) お よび(b)に示す. コンクリート抵抗は見かけの值であ るが，これは次項の解析に用いるためである.

塩水添加後における分極抵抗, コンクリート抵抗は, 平均電位が著しく卑変した時期以降にセル付近の值が 減少 ${ }^{6)}$ し, 自然電位結果と同様な腐食傾向を示してい る. L1 の 1075 時間経過時において, 塩水添加セル からの距離 $1200 \mathrm{~mm}$ 以上における分極抵抗およびこ ンクリート抵抗が, $1200 \mathrm{~mm}$ 以下に比較して大きな
值を示している. また, 供試体 S1 の切り離し時にお けるセル付近以外の分極抵抗とコンクリート抵抗は, 塩水添加後 341 時間より 1709 時間の方が大きい. 後 述する腐食減量測定時において, 供試体 L1, S1 の鋼 板とコンクリート間に付着切れは認められなかった. したがって，このような現象は，不動態皮膜形成の進 行，およびコンクリートと鋼板間の乾燥が進んだため に生じたものと考えられる. なお，L1 と S1 のコンク リート抵抗が異なっているのは, 測定時期の環境, あ るいはコンクリートの水分状態などの違いが影響を与 えたものと考えられる.

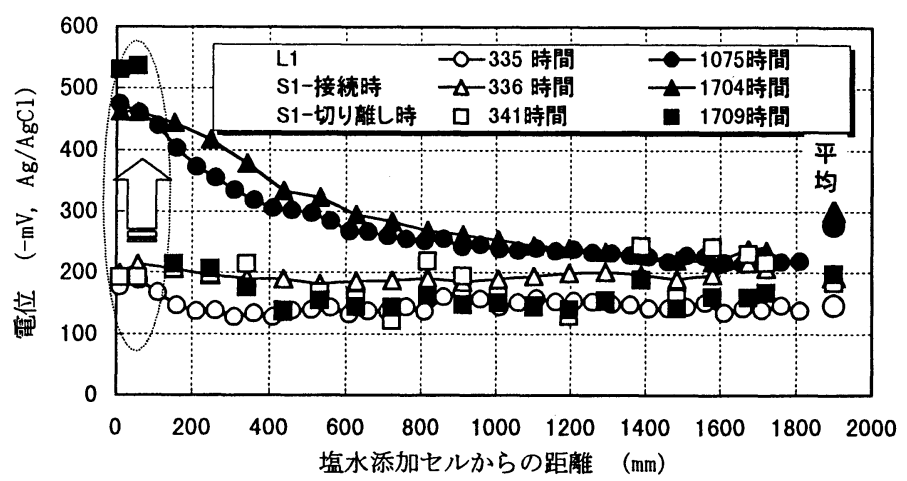

図-3 塩水添加後における L1, S1 の電位分布

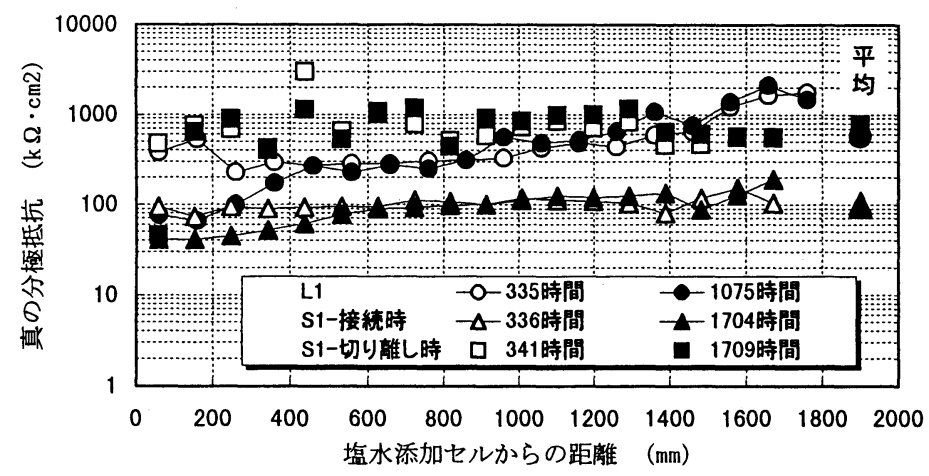

(a) 分極抵抗分布

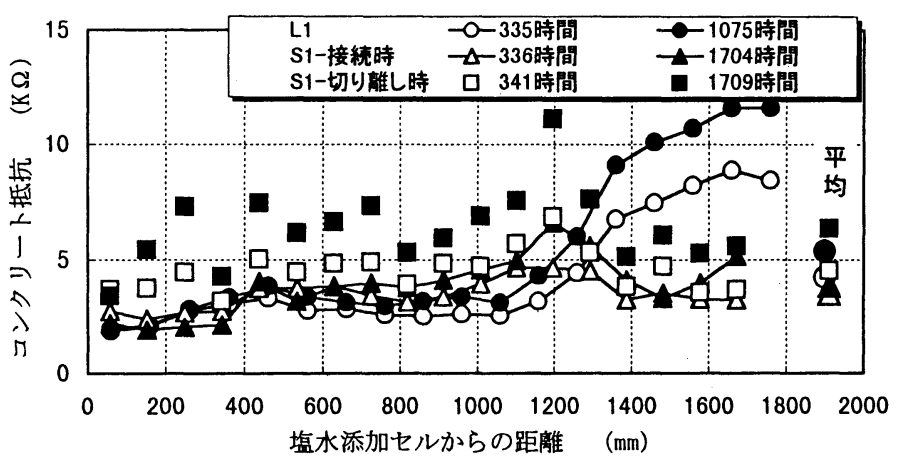

(b) コンクリート抵抗分布

図-4 塩水添加後におけるL1, S1 の分極抵抗，コンクリート抵抗の分布 
表-3 各測定と解析によって得られる腐食の場合分け

\begin{tabular}{|c|c|c|}
\hline & $\begin{array}{c}\text { L1 : 大銅板 } \\
\text { (露出面 : } 15 \times 1810 \mathrm{~mm})\end{array}$ & $\begin{array}{c}\mathrm{S} 1: \text { 小銅板 } \\
\text { (露出面 : } 15 \times 95 \mathrm{~mm} \times 18 \text { 枚 }+10 \mathrm{~mm})\end{array}$ \\
\hline 連続した銅板のマクロセル腐食 & L1-MA & S1-MA \\
\hline 連続した銅板の腐食 & L1- MA•mi & $\mathrm{S} 1-\mathrm{MA} \cdot \mathrm{mi}$ \\
\hline 分離した䤡板のミクロセル腐食 & & $\mathrm{S} 1-\mathrm{mi}$ \\
\hline
\end{tabular}

\section{(2) 测定結果の解析}

ここで，3.(1)b)の測定結果を用いて腐食の解析を 行う. 測定と解析で得られる腐食の場合分けを衣-3 に示す。

なお，測定値および解析値から算出する鋼板の推定 腐食量 $(W)$ は次式によって求めた.

$$
W\left(\mathrm{~g} / \mathrm{cm}^{2}\right)=\frac{a}{c} \int I_{c o r r} d t=\frac{a}{c} \int K\left(1 / R_{p}\right) d t
$$

ここで, $I_{\text {oorr }}$ :腐食電流密度 $\left(\mathrm{A} / \mathrm{cm}^{2}\right), K$ : 比例定数 $(\mathrm{V})$, $R p:$ 分極抵抗 $\left(\Omega \cdot \mathrm{cm}^{2}\right), a$ : 鉄を 2 価とし原子量を価数で除 した值 $(27.9 \mathrm{~g}), c$ : ファラデー定数 $(96500 \mathrm{C})$

ここで，表-3に示されている L1，S1 の両者から 検討する腐食のケースは以下のように分類される.

L1 : マクロセル解析から推定される腐食 (L1-MA:(1)) と分極抵抗加推定される腐食 (L1-MA・mi:(2)

$\mathrm{S} 1$ : 鋼板のリード線接続時におけるマクロセル解析 から推定される腐食 (S1-MA：(3)）と各点の分 極抵抗から推定される腐食 (S1-MA·mi : (4)), 鋼板の接続を切った場合の分極抵抗から推定され るミクロセル腐食 (S1-mi : (5))

一般に，マクロセル腐食の検討は L1 におおける(1)を 解析することである. (2)の検討はマクロセル腐食とミ クロセル腐食全体の推定を行うものであるが，図-3 およひ図ー4に示したように，腐食部が非腐食部に対 しても見か计上電位を卑変させるような影響を与える ことが考えられる.このため, 腐食部付近の非腐食部 も腐食と見なす場合があり，腐食部のみの厳密な值を 得ることは難しいものと考えられる. 一方，S1 のケ 一スは, (4)と(5)の比較から(2)の検討が可能となり，さ らに，(1)との比較も可能である. このように，S1 の ケースを検討することは，マクロセル腐食とミクロセ 儿腐食を個別に評価し，L1 のような一般的なケース を検郡する上でも重要と考えられる.

なお， $\mathrm{S} 1$ の分離された状態では，各鋼板内でマク ロセル腐食が生じていないものと仮定した.

次に，マクロセル腐食の数值解析について述べる.

\section{a）マクロセル腐食の解析}

一般に，コンクリート中の二次元電位 $(u)$ の分布 は（2）で示されるラプラス方程式が適用されている.

$$
\frac{\partial^{2} u}{\partial x^{2}}+\frac{\partial^{2} u}{\partial y^{2}}=0
$$

式は差分法 ")，あるいは有限要素法 ${ }^{8)}$ などによって 解かれているが，ここでは差分法を用いて以下のよう な条件と手順によって解析した。

(a) 電位は, 所定間隔 (L1:50mm, S1 : $95 \mathrm{~mm}$ ) 毎に測定された電位を多項式の曲線で近似し， 差分法で解析する間隔の $2.5 \mathrm{~mm}$ 毎に与えた.

(b) コンクリート厚を $20 \mathrm{~mm}$ と薄くしたことから, 鋼板表面電位を(a)で求められた電位と仮定 ${ }^{3)} し$ て与えた. また，境界条件として，コンクリー 卜表面および両端部をその内部方向の隣接電位 と等しいものとした. なお，供試体の軸方向の 解析節数点は, 725 点(L1) または 689 点 (S1) と し, 全解析節点数は (鋼板軸方向) $\times 8$ (コンクリ 一ト深さ方向 $)=5800$ 点 $(\mathrm{L} 1)$ または 5512 点 (S1)とした．計算は繰り返し計算とし，各節点 の電位とその直前に得られた電位との差が $0.0001 \mathrm{mV}$ 以下となるまで計算を繰り返した。

(c) (b) で得られた電位分布と比抵抗 $\left.{ }^{9}\right)$ に相当する コンクリート抵抗，あるいは各測定点から得ら れた分極抵抗を加えることによって鋼板表面に おける電流の流出入および腐食電流密度を求め た. なお，差分法の複雑な解析過程を避けるた め, コンクリート抵抗を供試体内で均一と仮定 し, 測定值の平均, 最大, 最小値のそれぞれを 用いた 3 通りについて解析を行った.

解析概要を図一5に示寸.

図-5に示寸ように，コンクリート中の $2.5 \mathrm{~mm}$ 間 隔に節点とその間に抵抗を配置し，たとえば鉛直方向 の場合，深さ方向の縦 $20 \mathrm{~mm}$ 区間に 8 個の直列抵抗 が軸方向の $40 \mathrm{~mm}$ 区間に 16 列あるとし，抵抗の直列 と並列の関係から節点間抵抗を求めた. 分極抵抗は, 真の分極抵抗を鋼板幅 $1.5 \mathrm{~cm}$ と区間 $0.25 \mathrm{~cm}$ の面積で 除して図-5に示される分極抵抗層の抵抗とした. 

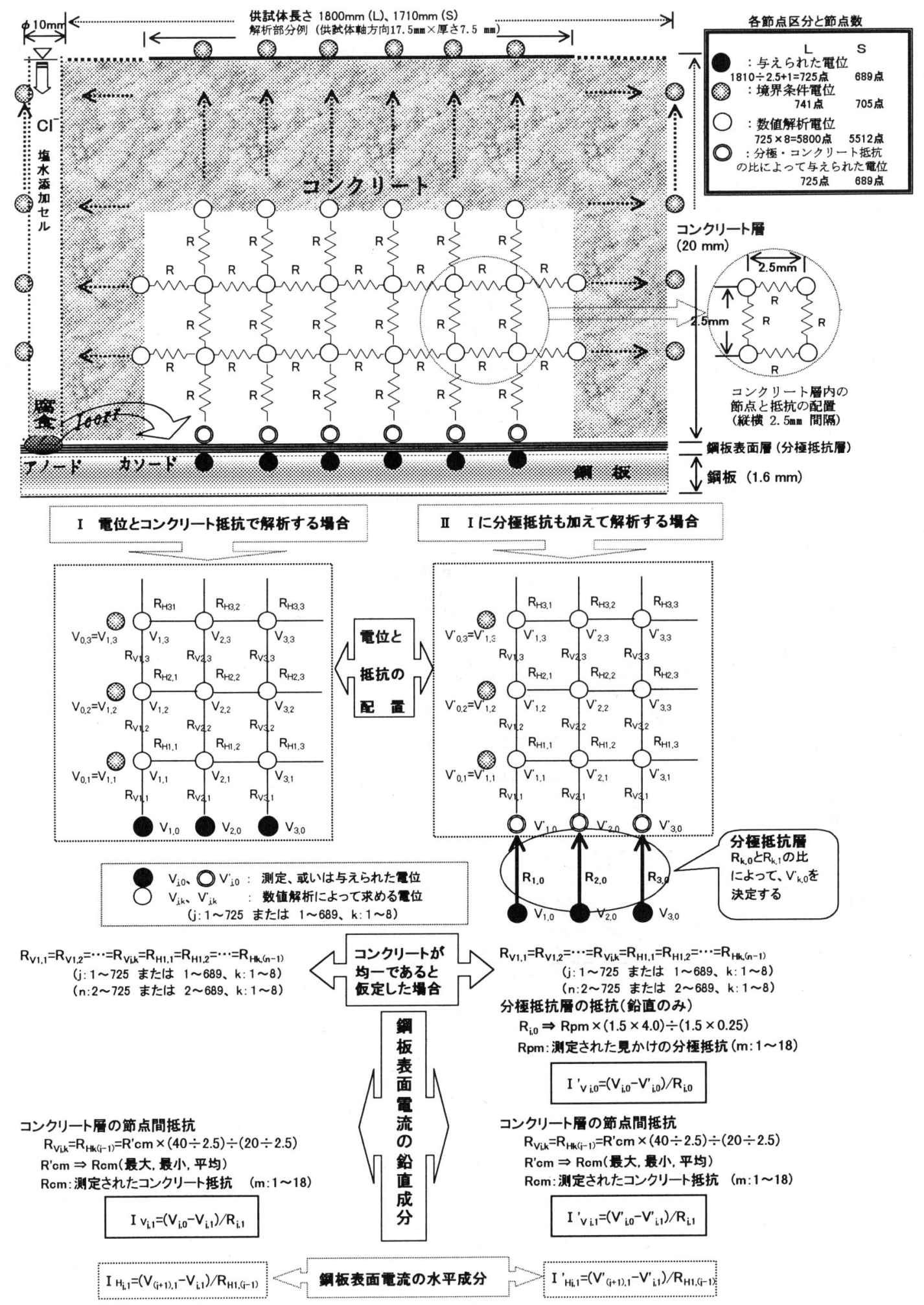

図-5 コンクリート中の電位分布および電流を求めるための解析概念 


\section{b）マクロセル解析による電位分布と電流分布}

鋼板表面電位として, 図一3に示されている卑変後 の電位分布へ多項式の近似曲線を適用した場合の分布 を図6に示す。

a)の マクロセル腐食解析手順 (a) で述べたように, マクロセル腐食解析のための電位分布は, 測定点以外 における值を多項式の近似曲線で回帰した値を用いて いる. 適用には種々の式を用いたが，4 次の多項式の 相関性が最も高く, $\mathrm{R}^{2}$ で 0.99 程度の精度が得られた。 また，10mm 毎の電位測定も行い近似式から得られ た值と比較したが，その適用に殆ど問題はないと判断
された.

解析で得られた鋼板表面の電流分布を图一7に示寸. 横軸方向を拡大した図では電位とコンクリート抵抗で 算出された L1, S1 の塩水添加セル付近における電流 が分極抵抗も考慮したものより大きい. しかし，これ は分布波形の見かけ上の違いであって，後で述べるア ノード電流量に相当する波形の積分值に大きな差は認 められなかった.この結果から，電位とコンクリート 抵抗で算出された電流量は，分極抵抗も加えた場合と 殆ど差はなく，腐食電流あるいはマクロセル腐食量に 関しても解析上大きな差は生じないものと考えられた。

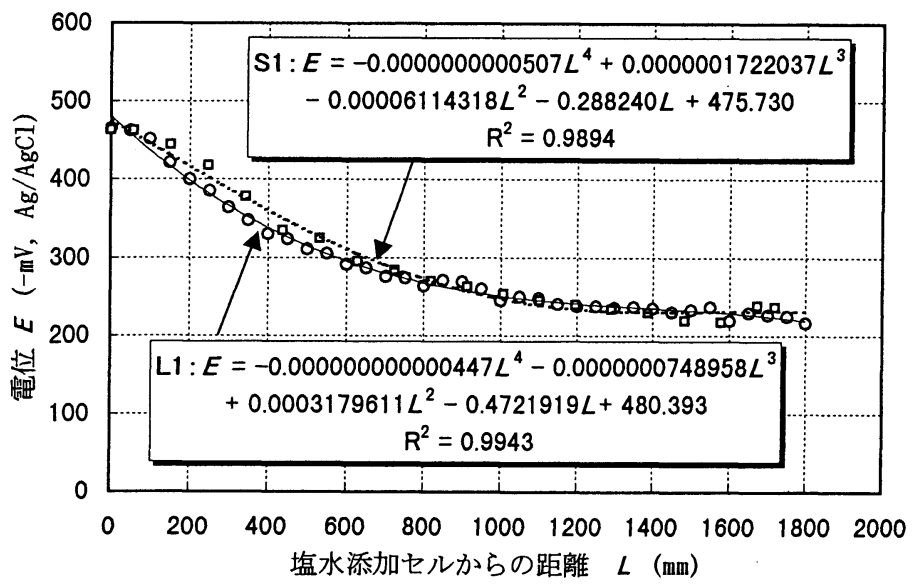

図-6 L1，S1 の電位分布と近似曲線の適用

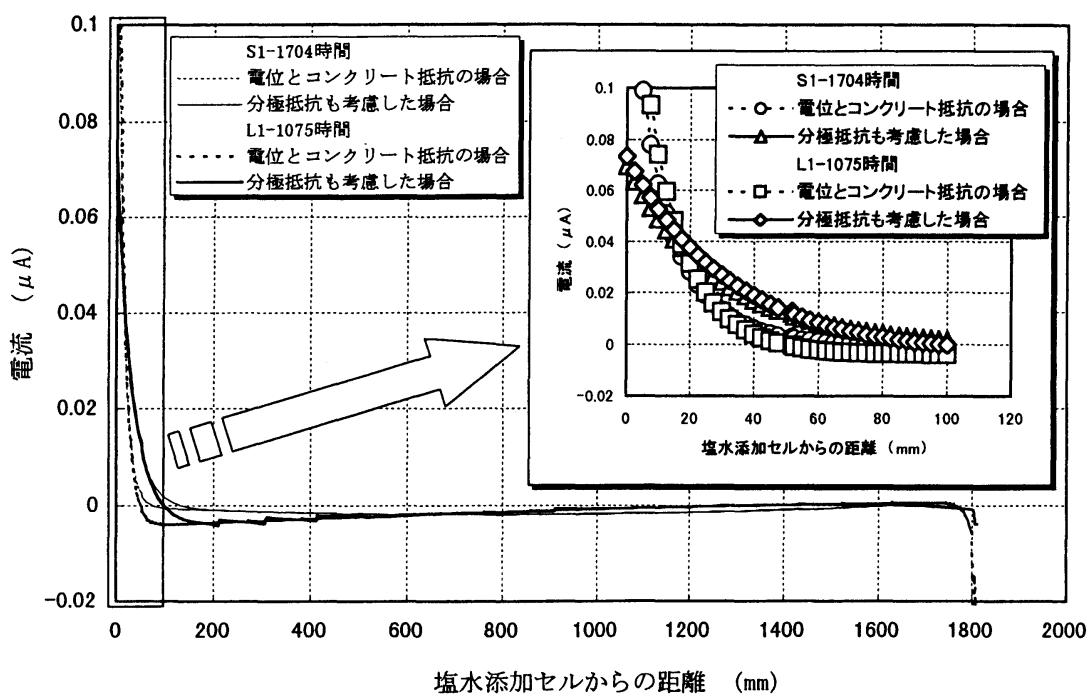

図-7 電位とコンクリート抵抗，あるいは分極抵抗を考慮した場合の電流分布（鋼板近傍鉛直成分） 
c） S1 のリード線接続状態（S1-MA）における鋼板

\section{間電流の実測之流出入電流の推定}

解析值と比較するため，無抵抗電流言により鋼板間 電流を測定し，各鋼板電流を求めた. 鋼板間電流を图 -8 (a), 各鋼板間電流の差加求められた塩水添加 セル鋼板を除く各鋼板電流を图-8の(b)に示寸.

電流測定は，電位，分極抵抗，コンクリート抵抗を 測定する際に行った.このため，コンクリートは養生 時の乾燥状態ではなく，一時的な湿潤状態下にある.

图-8 (b) に示される各鋼板電流をマクロセル腐食 による電流と仮定すると，アノード・カソード電流と して分ける必要がある. そこで，图一フに示された電 流分布と算出された各鋼板電流の関係から，図-9の
ような電流の流れによって表すことができるものと考 えられる.なお，この図性電流の流れを概略したもの で, 矢印の方向あるい骀始点上終点が全ての電流の方 向や大きさとして動密に表されているものではない，

これらの関係をもとに，图-8 (b)に示された各鋼 板電流 $\left(\mathrm{C}_{1} \sim \mathrm{C}_{17}\right)$ をカソード電流と見なし, その合計 を Sc から流出するアノード電流（Cc）と見なした場 合の電流分布を图-10 に示す.ここで，图-10 と図-7 の電流量に大きな差が認められるが，これは，図一7 が $2.5 \mathrm{~mm}$ 間隔の各節点における電流の分布を示してい るのに対し，図-10 が各鋼板 1 枚あたりの電流量を示 しているためである. 既に述べたように，これらの結 果は供試体を湿潤状態下で測定し得られたものである。

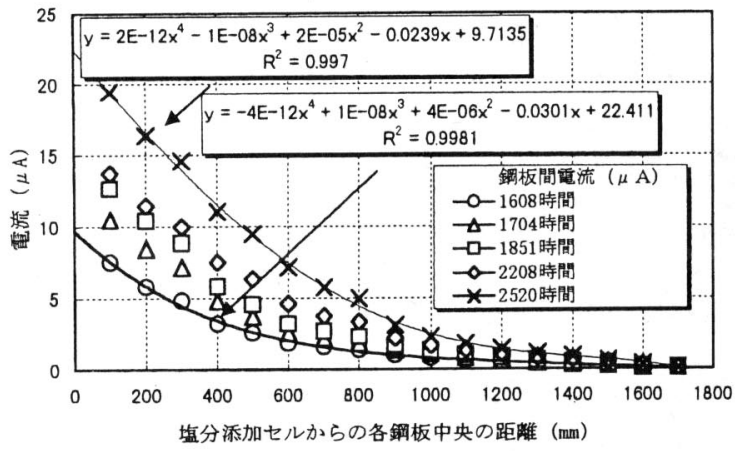

（a）無抵抗電流計により測定された鋼板間電流

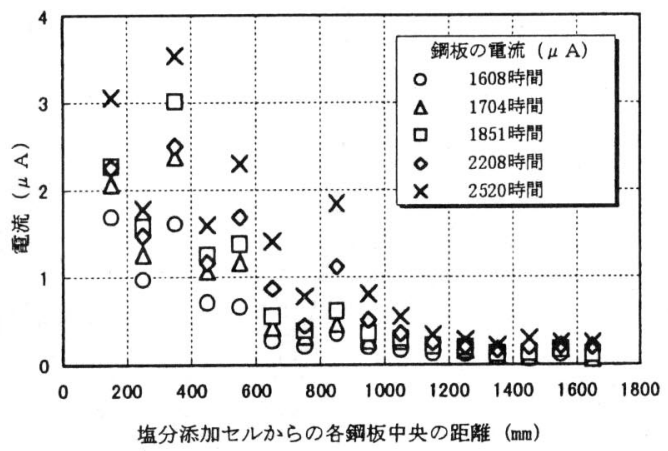

(b) 鋼板間電流から算出された鋼板電流

图-8 無抵抗電流言十により測定された鋼板間電流と算出された鋼板電流（湿澗状態下）

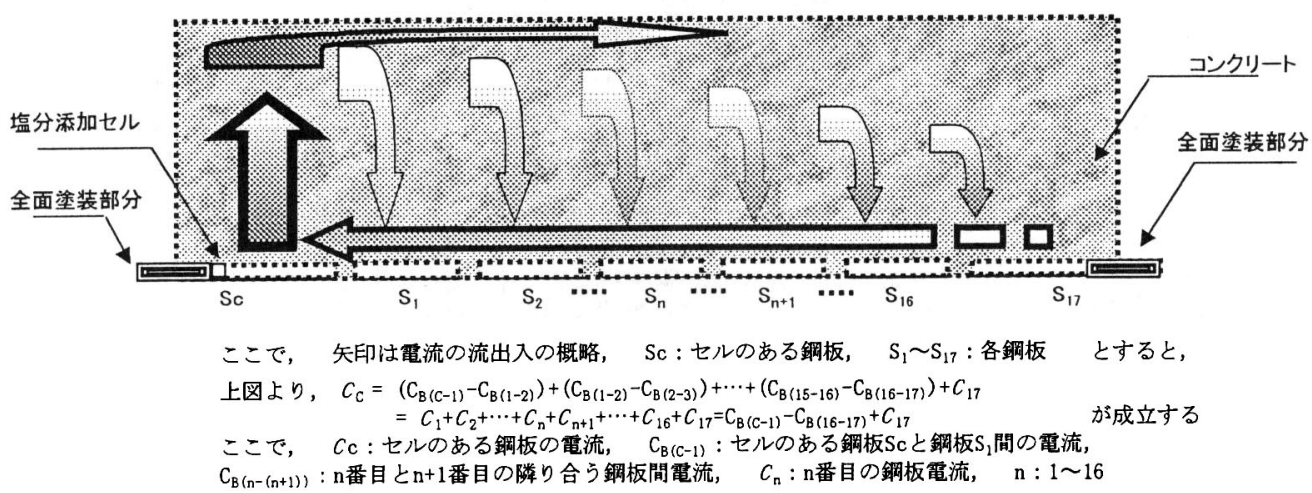

図-9 本研究のモデル試験におけるマクロセル電流の流れの概念 
一方, 測定時以外の供試体は乾燥状態にあるため, 乾 燥状態下で得られる電流を把握することも重要と考え られた. これは, 湿潤状態下における測定電流量と乾 燥状態下における測定電流量に差が生じるようであれ ば，解析結果に影響を与える可能性があると考えられ たからである.

そこで, 湿潤状態下 (各測定を行った直後) と乾燥 状態下 (各測定を行う直前) で測定された電流を比較 した. 塩水添加後 3192 時間の湿潤状態およひ乾燥状 態における鋼板間電流と鋼板電流の分布を图-11 (a)に, 湿潤およひ乾燥状態下におけるアノード電流の経時変 化を図一11(b)に示寸. なお, 乾燥状態下における鋼板 間電流は 2520 時間以降が実測で, それ以前は湿潤状
態下のみで測定を行ったため, 各鋼板間電流において 既知の乾燥一湿潤状態下の比を求めて推定している.

図-11(a)における乾燥状態下の鋼板間電流は, 湿潤 状態下に比較して小さくシフトした分布を示している. 図には各鋼板電流も示しているが，塩水添加セルに最 も近い鋼板電流は，湿潤状態と乾燥状態における差が 他の鋼板電流に比較して少ない.これは，塩水添加セ ル付近の鋼板が塩水によって常に湿潤状態にあるため, このような結果になったものと考えられる. したがっ て, 図-11(b)に示された各状態下におけるアノード電 流の差は, 塩水添加セル付近以外の電流の差によるも のと考えられる. これらの結果をもとに，次項で解析 値との比較検郡を行った.

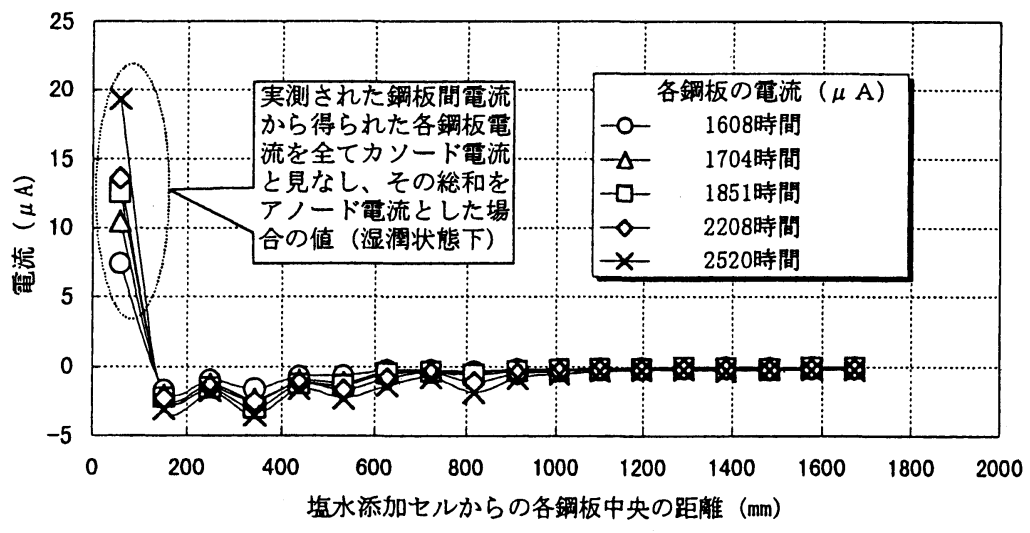

図-10 塩水添加セルのある鋼板をアノード，他の鋼板をカソードとした場合の鋼板電流の分布（湿潤状態下）

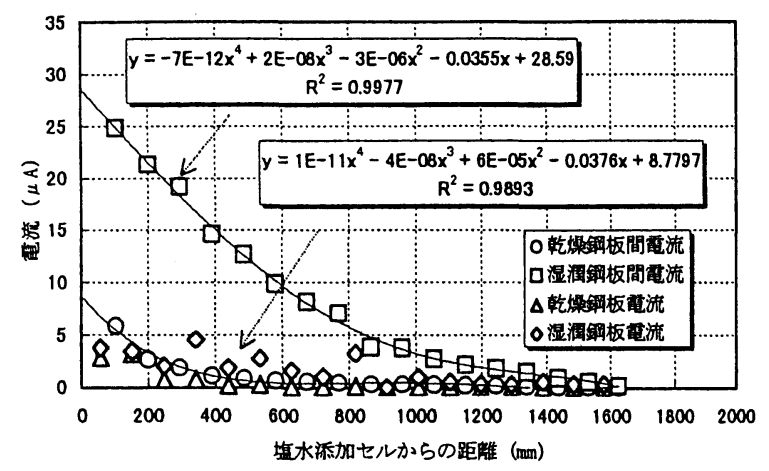

（a）鋼板間電流と鋼板電流分布（塩水添加後 3192 時間の場合）

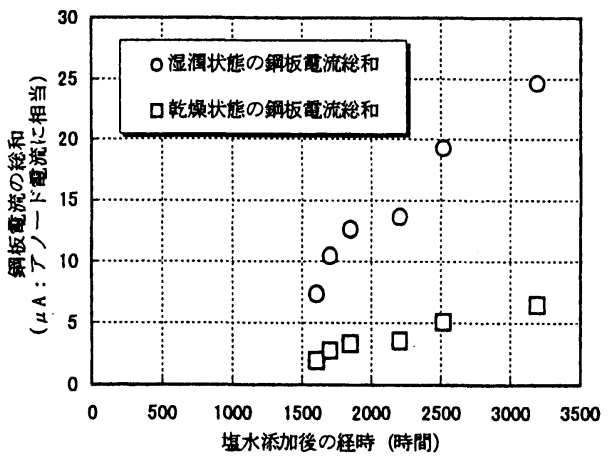

(b) アノード電流の経時変化

図-11 湿潤状態下と乾燥状態下における電流の関係 


\section{d） S1 のマクロセル腐食（S1-MA）に関する実測値 と解析値の評価}

解析結果による塩水添加セルのある鋼板 $(\mathrm{Sc})$ にお けるアノード電流の積分值を表-4に示す.

自然電位とコンクリート抵抗のみ，あるいは自然電 位とコンクリート抵抗に分極抵抗を考虑した場合の 2 通りについて解析を行った. この2通りのそれぞれに， コンクリート抵抗は同一供試体内で均一と仮定し，そ の最大值，最小值，平均值を用いて電流を算出した.

電位とコンクリート抵抗のみで求めた電流は分極抵 抗も考慮した場合より数\%増加する程度で, 顕著な差 は認められなかった. しがって，各場合で求めた電流 の分布に差は認められるものの, 解析結果には大きく 影響を与えないものと考えられる.アノード電流は, コンクリート抵抗の最小值を用いた場合が最も大きく， 平均值あるいは最大值を用いるとその值に応じて減少 する. 解析結果では $\mathrm{Sc}$ の長さ 0-105mm を僅かに超 えて電流が流出する場合も認められたが，流出電流の 殆どは 0-105mm 区間に存在する結果となった.この 結果から，電流の流出は塩水添加セルのある鋼板 Sc のみで生じているものと考えられる.
湿潤状態下で実測された自然電位，コンクリート抵 抗および分極抵抗による解析結果と, 鋼板間電流から 求められた乾燥状態下のアノード電流の経時変化を図 -12 に示寸. また, 図-12 の関係をもとに, 解析と乾 燥状態下のアノード電流の関係を図-13に示す.

图-12 およひ図-13 の乾燥状態下の各鋼板間電流汃 ら得られたアノード電流と解析から得られたアノード 電流を比較すると，解析値は鋼板間電流功得られた 值より低い結果となった。これらの関係は, 期間が 2500 時間まで解析值が実測值の約 50〜 60\%であるが， 期間がそれ以上になると約 20〜25\%となった. 乾燥 状態下の鋼板間電流から得られた值がマクロセル腐食 電流を表すものと仮定すると，本モデル試験に適用さ れた解析手法は，マクロセル電流を実際より低く見積 もる可能性がある. 解析值が低くなった原因として, コンクリート抵抗の影響があげられる. 今後，コンク リート抵抗の実測值を解析へどのように取り込むかな どの詳細な検討が必要と考えられる.これらの関係を 充分に把握することができれば，解析值から得られた マクロセル腐食に関する電流をより正確に推定するこ とが可能になるものと考えられる.

表-4 数値計算結果によるアノード電流量

(Sc 鋼板の 0-105m 区間て鋼板直上 0-2.5 $\mathrm{mm}$ を通過する電流の鉛直成分積分値)

\begin{tabular}{|c|c|c|c|c|c|c|}
\hline \multirow{3}{*}{$\begin{array}{l}\text { 塩水添加後 } \\
\text { の経時 } \\
\text { (時間) }\end{array}$} & \multicolumn{3}{|c|}{ 電位とコンクリート抵抗の場合 } & \multicolumn{3}{|c|}{ 分極抵抗も考愿した場合 } \\
\hline & \multicolumn{3}{|c|}{ 銅板直上0-2.5m畞を通過する電流 $(\mu \mathrm{A})$} & \multicolumn{3}{|c|}{ 鋼板直上0-2.5mmを通過する電流 $(\mu \mathrm{A})$} \\
\hline & Rc最大 & Rc最小 & $R c$ 平均 & Rc最大 & $R c$ 最小 & $R c$ 平均 \\
\hline 1608 & 0.3267 & 1.1189 & 0.5890 & 0.3261 & 1.0731 & 0.5839 \\
\hline 1704 & 0.4866 & 1.6764 & 0.8332 & 0.4804 & 1.5899 & 0.8105 \\
\hline 1851 & 0.4974 & 1.8982 & 0.8143 & 0.4897 & 1.8524 & 0.8006 \\
\hline 2208 & 0.4669 & 1.7667 & 0.8089 & 0.4657 & 1.7495 & 0.8049 \\
\hline 2520 & 0.5640 & 2. 2234 & 0.8884 & 0.5590 & 2.1940 & 0.8796 \\
\hline 3192 & 0.3957 & 2.0584 & 0.7381 & 0.3955 & 2.0507 & 0.7375 \\
\hline
\end{tabular}

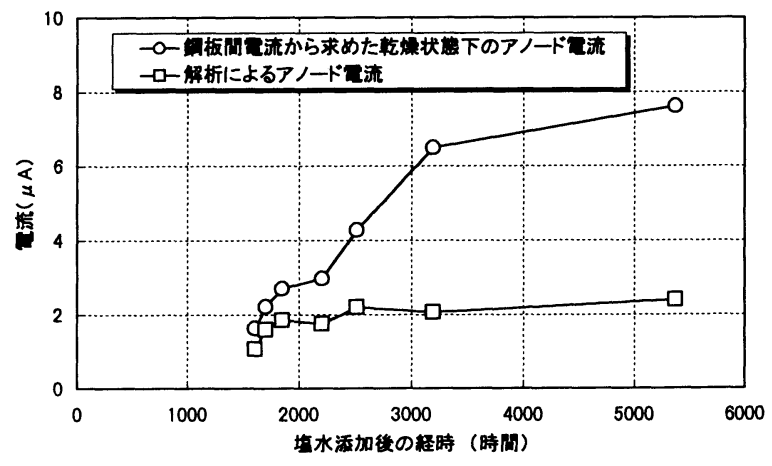

図-12 実測と解析によるアノード電流の経時変化

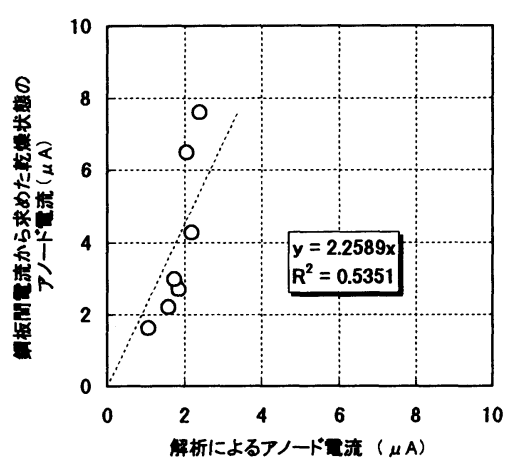

图-13 解析と実測のアノード電流の関係 


\section{e）S1 のミクロセル腐食に関する評洒}

既に述べたように，腐食はマクロセル腐食とミクロ セル腐食が同時に進行するものと考えられ，ここでは ミクロセル腐食について検郡を行った.

S1 のリード線を切り離した場合（S1-mi）と接続 時 (S1-MA・mi) における各分極抵抗力ら求めた腐食 電流密度の関係を图-14 に示す。なお，(1)式で使用さ れている係数 $K$ は既往の報告 10) 11) 12) 13 加ら $0.026 \mathrm{~V}$ と仮定した. 図中の楕円で囲まれた点はアノート部に 相当する塩水添加セルのある鋼板の電流密度を示して おり，その他はカソード部に相当する鋼板の電流密度 を示している．棈円外の関倸ほど著しくはないが，楕 円内の切り離し時と接続時の電流密度のほとんどは, 接続時が切り離し時より大きい.このことから，アノ 一ドと考えられる楕円内の接続時における分極抵抗か ら求められた電流量は, マクロセル腐食とミクロセル 腐食によるものを表していると考えられる.

接続時と切り離し時における電流量の総計の関係を 図-15 に示す. 接続時の総計は, 切り離し時に比較し て大きく，約5倍となっている.一般に，連続した鋼 材の腐食・非腐食部位あるいはアノード・カソード部 の特定を電位測定や分極抵抗測定から明確に区別する ことが難しい場合，実際にはカソート部であるにもか かわらず，その部分の自然電位や分極抵抗からアノー ドとして判断される可能性があるものと考えられる. このようなカソード部における分極抵抗から求めた電 流が加算される場合には, 図-14 に示されたアノード 部の電流密度は切り離し時も接続時と大きく変わらな いことから，全体の腐食電流密度が大きく見積もられ るものと考えられる. したがって，マクロセルとミク ロセル混在下の腐食を推定する場合，カソード部の電 流を加算しか心過大に見積もる可能性がある ${ }^{14)}$ ．しか し，図-15 に示した関係を把握しているならば，マク ロセル状態下においてもミクロセル腐食の把握は可能 と考えられる.

\section{f）推定席食量と腐食娍量}

S1 と L1 について, 各条件下で解析された腐食量 の累積值から推定される最終的な腐食量の算出過程を 表一5に示す.また，変一5から得られた結果および腐 食量の経時変化と腐食減量の関係を図-16(a)および (b)に示す. なお，目視によって腐食がセル付近と確 認されたため, 解析結果の採用と腐食减量の測定は, $\mathrm{S} 1, \mathrm{~L} 1$ ともセルのある鋼板（L1 は $\mathrm{S} 1$ の鋼板 $\mathrm{Sc}$ 部 分と同一長さ）の範囲に限定した. また，腐食減量の 算出は, 2. (4) (a)で述べたように樹脂塗料の減少, 付 着モルタルの影響などを考虑して行ったが，これらの
影響はほとんどなかった。

既に述べたように，本研究のモデル試験では，S1 の分極抵抗の逆数による腐食量は接続時と一時的な切 り離し時で僅かに接続時が大きいものの，大きな差は 認められなかった. 接続時の分極抵抗から得られる腐 食量に対して切り離し時の腐食量は約 $90 \%$ 以上であ り, 残りの腐食量は数\%程度となっている.

図-16(a)および表-5において, S1 の切り離し時の 腐食量をミクロセル腐食量, また，乾燥状態下の鋼板 間電流から得られる腐食量をマクロセル腐食量とする と, その合計は $120.2 \mathrm{mg}$ と推定され, 腐食減量 $123.3 \mathrm{mg}$ に近い值となった. 一方, 図-16(b) および 表-5において，L1 の塩水添加セル付近鋼板に関する 分極抵抗の逆数加得られる腐食量の累積は $50.7 \mathrm{mg}$ となった. S1 の切り離し時と接続時との関係から $50.2 \mathrm{mg}$ をミクロセル腐食量とし， L1 の解析によるマ クロセル腐食量を次に示す比によって,

[S1の実測による乾燥状態下のマクロセル腐食量]

[S1 の解析マクロセル腐食量 $]$

倍したものを L1 のマクロセル腐食量とすると合計は $63.1 \mathrm{mg}$ となり, 腐食減量 $72.1 \mathrm{mg}$ の約 $88 \%$ となった.

このように，実際より推定值は低いものの，S1 の ようなモデル (短い鋼板の接続と一時的な切り離し) を用いることにより，連続した鋼板の腐食についても 評価することが可能と考えられる. 特に，腐食部位を 的確に特定できる場合には，その鋼材に関するマクロ セル解析腐食量, および腐食部位付近の分極抵抗から 得られるミクロセル腐食量によって全腐食量の推定が 可能と考えられる.

このように，コンクリート構造物の鋼材腐食を検討 する場合には, (1) : 自然電位, 分極抵抗およびコンク リート抵抗などの測定結果からマクロセル腐食による 電流分布，アノードとカソード領域の明確な区分，お よびマクロセル腐食量の推定を行い, (2) : (1)で得られ たアノート部の分極抵抗の逆数からミクロセル腐食量 を推定し, (3) : (1)と(2)の関係から, 全腐食量を推定す ることが必要と考えられる.

一方，今回のモデル試験ではミクロセル腐食の全腐 食に占める割合が大きいが，これは供試体の置かれた 環境が室内乾燥の状態であり, マクロセル腐食が大き く進展しない環境であったことによるものと考えられ る. 今後は, マクロセル腐食解析結果の再現性, 分極 抵抗の逆数加ら腐食を求める場合の比例係数 $K$ の決 定などに関する検討とともに，主たる腐食がマクロセ ル腐食の場合も含め, 各種塩分環境下におけるこの種 の試験に関する詳細な検討が必要である. 


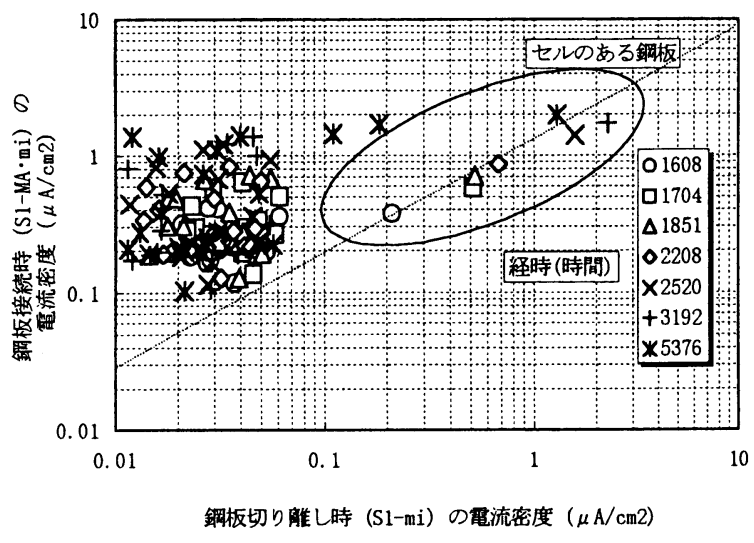

図-14 S1 の分極抵抗から求めた電流密度

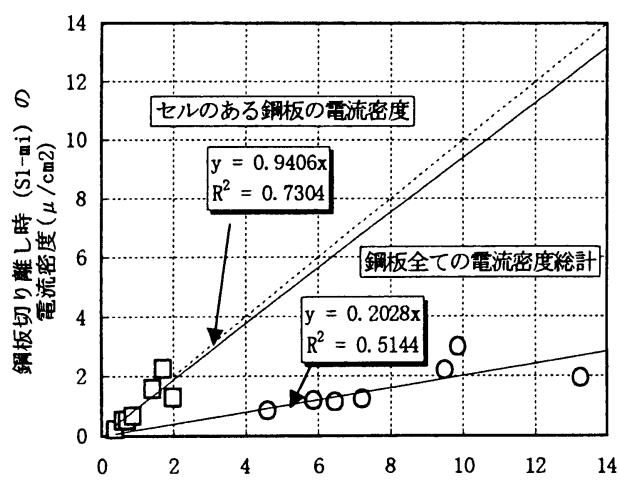

鋼板接続時 $(\mathrm{S} 1-\mathrm{MA} \cdot \mathrm{mi})$ の電流密度 $(\mu \mathrm{A} / \mathrm{cm} 2)$

図-15 S1 の分極抵抗から求めた電流密度 (セルのある鋼板と各鋼板の総計)

表-5 腐食减量測定までの累積値による各腐食量の関係と腐食减量との比較

\begin{tabular}{|c|c|c|c|c|c|c|}
\hline & 解 - MA & 実・乾・MA & $*$-mi & *-MA-mi & 推・総・腐 & 腐食減量 \\
\hline S1 & $\begin{array}{r}8.424 \text { (1) } \\
\text { (1) と(2) } \\
\text { 実·乾 } \cdot \mathrm{MA} / \text { 解 }\end{array}$ & $\begin{array}{l}23.750(2) \\
\text { 関係から } \\
M A=2.82(6)\end{array}$ & $\begin{array}{l}96.453 \text { (3). } \\
\text { (3)と(4)の } \\
\mathrm{S} 1-\mathrm{mi} / \mathrm{S} 1-\mathrm{M}\end{array}$ & $\begin{array}{c}97.522(4) \\
\text { 関係から } \\
\cdot \cdot \mathrm{mi}=0.989(7)\end{array}$ & $\begin{array}{l}(2)+(3) .5 \\
120.204(5)\end{array}$ & 123.300 \\
\hline L1 & 4.5748 & $\begin{array}{l}\text { (6) } と(8) \downarrow \\
12.899 \text { (1) }\end{array}$ & $\begin{array}{l}(7) と(9) \downarrow \\
50.158 \text { (1) }\end{array}$ & $\begin{array}{l}50.714 \text { (9) } \\
\rightarrow \rightarrow \rightarrow \rightarrow\end{array}$ & (10) 198 ? 63.05710 & 71.400 \\
\hline
\end{tabular}

注）解·MA : 解析のマクロセル腐食量, 実·乾·MA : 銅板間電流から得られた乾燥伏態下のマクロセル腐食量, S1-mi, S1-MA·mi : S1 の切り離し時, 接続持の分極抵抗から求めた腐食量, 推·総·腐 : 推定の総腐食量 * : S1 と L1 の両方があり，L1-mi はL1-MA・mi を S1-MA・mi と S1-mi の関係から推定したもの

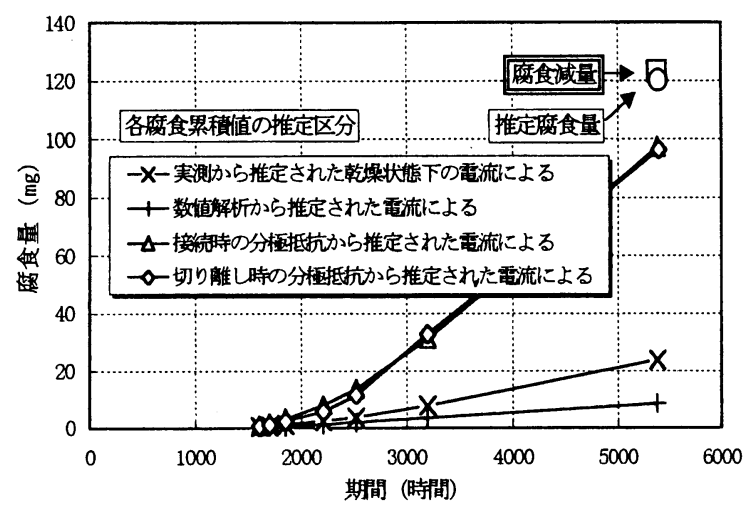

（a）S1 の推定腐食量と腐食減量

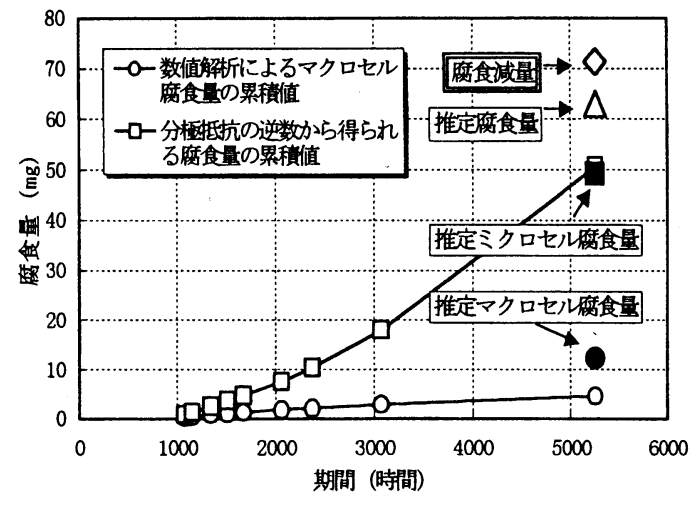

（b）L1 の推定腐食量と腐食减量

图-16 S1 とL1 の推定腐食量と腐食減量 


\section{4. 結合}

腐食部位を限定したモデル試験を行い，非破壊手法 と数值解析を用いてコンクリート中の鋼材腐食を評価 した. その結果，以下のような結論が得られた。

（1）供試体を一定期間水中環境と乾燥環境下に放置 し，塩水添加セルに塩水を定常的に添加したが，自然 電位，分極抵抗，コンクリート抵抗などの非破壊手法 により鋼板の腐食時期を特定することができた。

（2）供試体 L1 およびS1 のマクロセル腐食解析に おいて，解析に考慮する要因を自然電位とコンクリー 卜抵抗のみで行った場合と分極抵抗も加えた場合で電 流分布に差が生じるものの, アノード電流の総量に大 きな差は認められなかった。

（3）供試体S1 のリード線を接続した場合において， 解析から得られたアノード電流は，鋼板間電流の実測 から得られた值と比較すると大きな差が生じる場合も あるが，これらの関係を把握することは可能である.

（4）供試体 S1 のリード線を接続した場合とリード 線を一時的に切り離した場合において，分極抵抗から 求められた電流密度は，腐食部位のセル付近で接続時 が大きいものの，その差は小さく，他の部分では接続 した場合が切り離した場合より大きな值となった。

（5）本研究におけるモデル試験の場合，ミクロセル 腐食の全腐食量に占める割合が大きい結果となった. これは供試体が室内乾燥状態にあり，このような環境 条件が影響したものと考えられる.

（6）供試体 S1 のリード線を一時的に切り離した場 合の分極抵抗から得られた腐食量をミクロセル腐食と し，リード線を接続した場合のマクロセル電流量の解 析値と実測值の関係を検討した上で得られた腐食量を マクロセル腐食とすると，総腐食量の推定が可能とな り，一般的な場合に相当する L1についてマクロ・ ミクロ腐食量と総腐食量の推定が可能である.

したがって，鋼材腐食を各部分で測定される分極抵 抗のみで把握することは難しいと考えられ，自然電位， 分極抵抗とコンクリート抵抗，マクロセル腐食解析に よってアノードとカソードを的確に区分した上で， 、 クロセル・ミクロセル腐食を推定することが必要と考 えられる. 一方, マクロセル解析の再現性, ミクロセ ル解析に適用される $K$ 值の設定などが腐食の推定へ影 響を与えるため, 今後も各種塩分環境下におけるこの 種のモデル試験に関する詳細な検討が必要である.
葀活 : 本論文の作成にあたり，株式会社四国総合研究 所横田優氏に貴重なご助言を賜りました。ここに厚く 御礼申し上げます。

\section{参考文献}

1) コンクリート委員会腐食防食小委員会（305 委員会） 報告 : 鉄筋腐食・防食および補修に関する研究の現 状と今後の動向，コンクリート技術シリーズ 26 , 土木学会, 1997.

2) 宮川豊章 : Early chloride corrosion of reinforcing steel in concrete, 京都大学博士論文, 1985.

3) 小山理恵，矢島哲司，魚本健人，星野富夫 : 自然電 位法を用いた鉄筋腐食状態の推定方法に関する基磫 的研究，士木学会論文集，No.550/N-33，pp.13-21， 1996.

4) 長瀧重義，大即信明，守分敦郎，宮里心一 : 鉄筋二 ンクリート部材の断面修復部における腐食形成に関 する実験的研究，土木学会論文集，No.544/V-32, pp.109-119, 1996.

5）横田優，田村博 : 鉄筋腐食診断のための電気化学的 非破壊探查法, 非破壊検查, 第 47 巻, 第 9 号, pp.649645, 1998.

6) Elsener, B. : Corrosion Rate of Steel in Concrete From Laboratory to Reinforced Structures, Materials Science Forum, Vol247, pp.127-138, 1997.

7) 小林孝一，宮川豊章 : 分極抵抗法を用いた鉄筋腐食 の腐食速度評価に関する研究，土木学会論文集， No.669/V-50, pp.173-186, 2001.

8）本間利久, 田中康博 訳 : 有限要素法による電磁界 解析, Silvester, P. P. and Ferrari, R. L. 「FINITE ELEMENTS FOR ELECTRICAL ENGINEERS」, サイエンス 社, 1988.

9）関博，宮田克二，北峯博司，金子雄一 : 比抵抗によ るコンクリートの緻密性に関する実験的一考察，土 木学会論文集, No.451/N-17, 1992.

10）岡田清, 小林和夫, 宮川豊章, 本田哲 : 分極抵抗法 を用いた鉄筋腐食モニタリングによる補修基準につ いて，第5回コンクリート工学講演論文集，pp. 249252, 1983.

11）横田優 : 電気化学的手法によるコンクリート中の鉄 筋腐食評価，コンクリート工学年次論文報告集, Vol. 12, No. 1, pp. 545-550, 1990. 
12) Flis, J., Sabol, S., Pickering, H.W., Sehgal, A, Osseo- Asare, K, and Cady, P. D. : Electrochemical Measurements on Concrete Bridges for Evaluation of Reinforcement Corrosion Rates, Corrosion, Vol49, No.7, pp.601-613, 1993.

13) Andrade, C., Castelo, V., Alonso, C., and González, J.A : The determination of the corrosion rate of steel embedded in concrete by the polarization resistance and $\mathrm{AC}$ impedance methods, Proc. of
Int. Symp., Williamsburg, USA, ASTM STP 906, pp.43-63, 1986.

14) Gulikers, J. : Numerical Simulation of Corrosion Rate Determination by Linear Polarization, Measurement and Interpretation of the On-site Corrosion Rate, Proc. of Int. Workshop MESINA, Madrid, Spain, RILEM Publications, pp.145-156, 1999.

\section{A STUDY OF MACRO-CELL AND MICRO-CELL CORROSION OF STEEL IN CONCRETE}

\section{Tatsuo KAWAHIGASHI, Koichi KOBAYASHI and Toyoaki MIYAGAWA}

In order to evaluate the corrosion of reinforcing steel in concrete with non-destructive methods is one of indispensable items for maintenance of concrete structures. It is expected that some evaluation methods are established in this subject. Through a model experiment using different sized steel plates, the change in electrochemical response of steel was grasped with non-destnuctive methods such as half-cell potential, polarization resistance (AC impedance), and electric current. The numerical analysis of macro-cell corrosion and calculation of micro-cell corrosion were performed by applying experiment results. This study showed that it was possible to divide the corrosion into the macro-cell and micro-cell corrosion and was possible to estimate the steel corrosion from these results. 